\title{
Distributional data and taxonomic notes on the flea Strepsylla (Siphonaptera: Ctenophthalmidae: Neopsyllinae: Phalacropsyllini)
}

\author{
Datos de distribución y notas taxonómicas de las especies de Strepsylla (Siphonaptera: \\ Ctenophthalmidae: Neopsyllinae: Phalacropsyllini)
}

\author{
Roxana Acosta \\ Museo de Zoología "Alfonso L. Herrera”, Departamento de Biología Evolutiva, Facultad de Ciencias, Universidad Nacional Autónoma de México. \\ Apartado postal 70-399, 04510 México, D. F., México. \\ \roxana_a2003@yahoo.com.mx
}

\begin{abstract}
Strepsylla Traub, 1950 is considered a New World flea genus, parasitizing, in most cases, species of Muridae, particularly peromyscines. Thirteen species of Strepsylla are addressed with respect to their taxonomic characters, host preferences and geographic distribution. A detailed list of material is included.
\end{abstract}

Key words: parasites, New world fleas, peromyscines, taxonomic characters.

Resumen. Strepsylla Traub, 1950 es considerado un género de pulgas del nuevo mundo, que en la mayoría de los casos parasitan múridos, particularmente peromisinos. Se comentan algunos de los caracteres taxonómicos, preferencia de huéspedes, distribución geográfica y el material examinado de las 13 especies del género.

Palabras clave: parásitos, pulgas del nuevo mundo, peromisinos, caracteres taxonómicos.

\section{Introduction}

Strepsylla Traub, 1950 belongs to the tribe Phalacropsyllini Wagner, 1939, which contains 6 genera and 60 species, the majority of which are distributed in the New World, except for 4 Palearctic species of Catallagia (Hopkins and Rothschild, 1962; Adams and Lewis, 1995). Strepsylla has the southernmost distribution in the Americas (Acosta, 2010). Strepsylla was described from the state of Michoacán (Traub, 1950). Species assigned to this genus are distributed from northern Mexico to Panama. Strepsylla is considered 1 of 2 genera endemic to the Caribbean subregion, related to the New World scheme of biogeographical subdivision in Medvedev $(1996,2000)$. The 13 species are all primarily parasites of peromyscine and microtine rodents, but they occur occasionally on other rodents (Acosta, 2010).

My objectives are to provide new taxonomic and distributional information, and elucidate the hosts of the species of the Strepsylla.

\section{Materials and methods}

Data were obtained from the literature and specimens from different collections. I examined 205 slide mounted

Recibido: 10 diciembre 2010; aceptado: 12 enero 2011 specimens, including the primary types of 5 species. Specimens were examined with an Olympus vanox-T microscope (Olympus Corporation, Tokyo, Japan). Specimens were obtained on loan from the following institutions: AMNH, American Museum of Natural History, New York, New York; BMNH, Department of Entomology, The Natural History Museum, London, U.K.; CMNH, The Carnegie Museum of Natural History, Pittsburgh, Pennsylvania; IBUNAM, Laboratorio de Acarología, Instituto de Biología, Universidad Nacional Autónoma de México, México, D.F., Mexico; BYU Collection, Monte L. Bean Life Science Museum (MLBLSM), Brigham Young University, Provo, Utah; RPE, Personal Collection of Ralph Eckerlin, Northern Virginia Community College (NVCC), Annandale, Virginia; MZFC-S, Colección de Siphonatera, Museo de Zoología, Facultad de Ciencias, Universidad Nacional Autónoma de México, Mexico, D.F., Mexico; and USNM, Department of Entomology, National Museum of Natural History, Smithsonian Institution, Washington, D.C.

\section{Results}

Strepsylla dalmati Traub and Barrera, 1955

Strepsylla dalmati Traub and Barrera, 1955: 541.

Distribution. Guatemala, Costa Rica, Honduras, and Panama. 
Hosts. Muridae: Peromyscus aztecus (Saussure, 1860), P. mexicanus (Saussure, 1860), P. nudiceps (J. Allen, $1891)=$ P. mexicanus, Peromyscus sp., Reithrodontomys mexicanus (Saussure, 1860), Scotinomys teguina Alston, 1877, and S. xerampelinus Bangs, 1902; and Sciuridae: Sciurus granatensis Humboldt, 1811.

Comments. The widely separated distribution records for this species support the need for additional collecting and suggest that the southernmost range of the genus remains yet to be discovered. The host preference is peromyscine rodents. It shares with other species the flap of the sternite IX with spiniform bristle not curly (Fig. 1) as $S$. davisae, $S$. machadoi, and $S$. schmidti. In the specimens of $S$. dalmati examined from Costa Rica, Honduras and Panama, the last segment of the metatarsus has 5 pairs of plantar setae with the proximal pair displaced mesad, as in the other species of the genus. This character was diagnostic in the original description of the specimens from Guatemala (Traub and Barrera, 1955). It is possible that the absence of the character is only on the holotype, which was the only specimen of the species not reviewed. Specimens from Costa Rica have 2 setae near the apex of the movable process that are slightly longer than in the holotype (compare figures from original publication) and the movable process is somewhat wider; plus they have 3 long setae in sternite VIII instead of 2. I consider these differences within the range of geographic variation, because the majority of the remaining characters of the species are consistent.

Material examined. Costa Rica. San José. $10 \mathrm{~km} \mathrm{~S}$ Empalme, $2560 \mathrm{~m}, 1-2 / \mathrm{I} / 1993,1$ male, 7 females ex $P$. mexicanus, R. P. Eckerlin (RPE); 14 km S Empalme, 2499 m, 29/III/1987, 1 male, 1 female ex P. mexicanus, R. P. Eckerlin (RPE); idem 31/XII/1992, 1 female ex Scotinomys sp., R. P. Eckerlin (RPE); 14 km SE Empalme, 2499 m, 23, 29/III/1986, 3 males, 2 females ex S. xerampelinus and $P$. nudipes $=P$. mexicanus, R. P. Eckerlin (RPE); $14 \mathrm{~km}$ S Empalme, 2499 m, 29/III/1987, 1 male, 1 female ex P. mexicanus, R. P. Eckerlin (RPE); Cerro de la Muerte, 3352 m, 4/I/1999, 1 male ex $P$. mexicanus, R. P. Eckerlin (RPE); 4 km S, 2 km E, Ojo de Agua, 21/V/1986, 1 male ex P. mexicanus, R. P. Eckerlin (RPE). Honduras. Depto. Lempira. Parque Nacional Celaque, Naranjo, $2560 \mathrm{~m}$, 4, 6, 8, 11/II/1998, 6 males, 4 females ex $P$. aztecus, $P$. mexicanus, $R$. mexicanus, and Scotinomys teguina, R. P. Eckerlin (RPE); Don Tomas, 2083 m, 4-5, 7/II/1998, 2 males, 1 female ex $P$. aztecus, and S. teguina, R. P. Eckerlin (RPE); Depto. Francisco Morazan, Parque Nacional La Tigra, 1900-2100 m, 1-5/I/1995, 3 males, 4 females ex Peromyscus, ex P. aztecus, R. P. Eckerlin (RPE). Panama. Chiriqui. Bambito - Cerro Punta, camino Boquete, 1828-2346 m, 8-9, 14/III/1962, 2 males, 3 females ex $P$. nudipes $=P$. mexicanus, Keenan and Tipton
(MWH); idem 7150 m, 12/III/1962, 1 male ex $P$. nudiceps $=P$. mexicanus, Keenan and Tipton $(\mathrm{MWH})$; Prov. Cerro Punta, Abore Marinz Dairy, 25/IV/1960, 1 female ex Sciurus granatensis, Keenan and Tipton (BMNH).

Strepsylla davisae Traub and Johnson, 1952 Strepsylla davisae Traub and Johnson, 1952: 4. Distribution. Mexico (Durango).

Host. Muridae: Peromyscus sp.

Comments. Distal arm of sternite IX (Fig. 2) as in S. fautini more or less same width, apically with 2 slender setae. Neither the host preference nor the distribution can be accurately inferred with the existing data.

Material examined. Mexico. Durango: $11.2 \mathrm{~km} \mathrm{NE}$ Revolcaderos, $2438 \mathrm{~m}, 29 / \mathrm{VII} / 1965,2$ males ex Peromyscus sp., J. J. O'Keefe and R. Kronmeyer (CMNH, USNM); 12.8 km S El Salto, 9/VIII/1965, 1 female ex Peromyscus sp. (USNM).

Strepsylla fautini Traub, 1950

Strepsylla fautini Traub, 1950: 80; Traub and Johnson 1952: 4.

Distribution. Mexico (Michoacán).

Host. Muridae: Peromyscus hylocetes Merriam, 1898.

Comments. Male distinguishable from other species by the double spiral of the twisted spiniform on distal arm of sternite IX (Fig. 3). Distal arm of sternite IX not unlike that of $S$. davise or $S$. longicauda, but straighter; apex of the flap longer than distal arm. Crochet with 1 arm as in S. machadoi, but slender at the apex and wider at the base (Fig. 4). Inmovable process square as in S. ixtlanensis and S. mina. Female unknown. Neither the host preference nor distribution can be accurately inferred with the existing data.

Material examined. Mexico. Michoacán: Mount Tancítaro, 2377 m from P. hylocetes. Holotype male, Field Museum of Natural History (Chicago) (FMNH). The paratype male collected from same locality as the holotype, coll. by R. Traub.

Strepsylla ixtlanensis Acosta, 2010

Strepsylla ixtlanensis Acosta, 2010: 294.

Distribution. Mexico (Oaxaca).

Host. Muridae: Peromyscus difficilis.

Comments. Separable from all known Strepsylla species in that the dorsal margin of male fixed process is somewhat sinuate instead of convex or almost straight (Fig. 5) as in $S$. queretana and $S$. taluna. Movable process as wide as that of $S$. dalmati, $S$. taluna, and $S$. queretana. This species is similar to $S$. davisae, by the spiculose flap and the spiniform of the distal arm of the sternite IX (Fig. 6), and the setae of the fixed and movable processes. The hyperdevelopment of 
lateral lobes is unique from other species. Known only from males (Acosta, 2010). Neither the host preference nor the distribution can be accurately inferred with the existing data. Material examined. Mexico. Oaxaca: Ixtlán, $8.75 \mathrm{~km} \mathrm{SE}$ de Santa María Yavesía, $19^{\circ} 10.2^{\prime} \mathrm{N}, 96^{\circ} 22.5^{\prime} \mathrm{W}$, fir forest, 2990 m. Holotype male 06073 MZFC-S, 24/IV/2002, G. Ambriz. Paratypes (3 males) 06072, 06074 and 06075 MZFC-S, coll. by G. Ambriz, the locality and host for these specimens are the same as the holotype.

Strepsylla longicauda Acosta, 2010

Strepsylla longicauda Acosta, 2010: 292.

Distribution. Mexico (Durango and Nuevo León).

Host. Muridae: Peromyscus sp.

Comments. Separable from all known Strepsylla species in that the dorsal margin of male fixed process (Fig. 7) is straight instead of somewhat sinuate as $S$. queretana and $S$. ixtlanensis and in that there is a dense patch of many thin short setae. The number of long setae on movable process less than in S. mina and S. machadoi. The missing information of the type host species supports the need for additional collecting to determine host preferences (Acosta, 2010).

Material examined. Mexico. Nuevo León: Cerro Potosí. Holotype male, coll. V. J. Tipton, 1964 (MWH). Paratypes. Cerro Potosí, 1 male ex unknown, V. J. Tipton, 1964 (MWH). Durango: $804 \mathrm{~m}$ SE Buenos Aires, $2651 \mathrm{~m}, 3 /$ VIII/1965, 1 male, 1 female ex Peromyscus sp., J. J. O'Keefe, E. Fisher, and R. Kronmeyer (CMNH).

Strepsylla machadoi Barrera and Traub, 1963

Strepsylla machadoi Barrera and Traub, 1963: 191.

Distribution. Mexico (Guerrero).

Hosts. Muridae: Oryzomys alfaroi (J. A. Allen, 1891), Megadontomys thomasi (Merriam, 1898), Peromyscus boylii levipes Merriam, $1898=$ P. levipes Merriam, 1898, P. megalops (Merriam, 1898), P. osgoodomys banderanus (J. A. Allen, 1897) = Osgoodomys banderanus (J. A. Allen, 1897), and Peromyscus sp.

Comments. Although dissimilar to most species in the genus, S. machadoi resembles $S$. villai and S. longicauda more than the other species. S. machadoi has marginal setae on flap of distal arm of sternum IX (Fig. 8); in all other species, the dorsal margin of fixed process is nearly straight or only slightly concave; there is no posterior hump, and there is a small sinus on the posterior margin of the sternite VIII. Further, in S. machadoi sternite VIII is definitely higher than wide, whereas in $S$. villai, it is wider than high; in fact in none of the other species is this segment significantly longer than broad. Crochet is different from other species of the genus (Fig. 9). Specimens have been collected in the Mexican state of Guerrero, so I assume a restricted geographical distribution in Guerrero. Specimens were collected from 4 species of rodents; most of the records were taken from genus Peromyscus and 1 on the species P. megalops. The type series was collected in Mexico; Guerrero Puerto Chico, Omiltemi from Peromyscus sp. and Chichihualco, Camotla, ex Osgoodomys banderanus.

Material examined. Mexico. Guerrero: Chichihualco, Puerto Chico, Camotla 16/V/1960, male holotype, 1 female paratype ex $P$. osgoodomys banderanus = Osgoodomys banderanus, C. Machado and A. Barrera (MZFC-S); 1.6 km SW of Omiltemi, 2212 m, 3-6, 17/ IV/1963, 9 males, 2 females ex Peromyscus, A. D. Stock and A. Shaw (MZFC-S, CMNH, USNM); Toro Muerto, San Miguel Totolapan, 1/IV/1983, 1 male ex Peromyscus, J. Juárez G. (MZFC-S); km 14 carr. Puerto del Gallo - El Paraíso, 26/XI/1983, 1 male, 2 females ex M. thomasi, J. Juárez G. (MZFC-S): Agua Fría, 22 km SW de Yextla, 2600 m, 11/IV/1963, 1 male, 10 females ex Peromyscus, T. Álvarez (BMHN, MZFC-S); Chilpancingo, Omiltemi, Cañada de agua fría, 6/VIII/1985, 1 male, 4 females ex M. thomasi, J. Juárez G. (MZFC-S); Los Retrocesos, 3/ IX/1983, 1 male ex O. alfaroi, J. Juárez G. (MZFC-S); Tlacotepec, Puerto del Gallo, 1/IX/1983, 1 male ex $P$. megalops, J. Juárez G. (MZFC-S); 29/III/1983, 1 female ex M. thomasi, J. Juárez G. (MZFC-S); 30/VII/1983, 1 female ex P. boylii levipes $=$ P. levipes, J. Juárez G. (MZFC-S); $7 /$ VIII/1983, 1 female ex unknown, J. Juárez G. (MZFC-S); 30/VIII/1983, 3 females ex P. megalops, J. Juárez G. (MZFC-S); 4/XII/1984, 1 female ex Peromyscus, J. Juárez G. (MZFC-S); Tlacotepec, El Iris, $7 \mathrm{~km} \mathrm{~W}$ de Puerto del Gallo, 3/VII/1983, 1 male ex P. megalops, J. Juárez G. (MZFC-S); 31/VII/1983, 1 female ex P. megalops, J. Juárez G. (MZFC-S); idem 25/XI/1983, 1 female ex Peromyscus, J. Juárez G. (MZFC-S): Leonardo Bravo, Carrizal de Bravo (17³5'20.1'N 99 50'21.1”W), 2687 m, 16/IV/2003, 2 females ex Peromyscus, H. Olguín and A. Garza (MZFC-S); Chilpancingo, 4 km N de Omiltemi, 10/IV/1983, 2 females ex undetermined Peromyscus sp., P. megalops, JJG (MZFC-S); km 18, carr. Puerto del Gallo - El Paraíso, La Golondrina, 7/VIII/1983, 1 female ex Peromyscus, J. Juárez G. (MZFC-S); Tlacotepec, El Iris, 2/ IX/1983, 1 female ex M. thomasi, J. Juárez G. (MZFC-S); 25/XI/1983, 2 females ex Peromyscus, and M. thomasi, J. Juárez G. (MZFC-S); 5/XII/1984, 1 female ex P. megalops, J. Juárez G. (MZFC-S); La Golondrina, 28/X/1983, 2 females ex P. megalops, J. Juárez G. (MZFC-S); Nueva Delhi, 23/VII/1984, 1 female ex Peromyscus, J. Juárez G. (MZFC-S).

Strepsylla mina Traub, 1950

Strepsylla mina Traub, 1950: 77. 
Distribution. Mexico (Distrito Federal, Estado de México, Hidalgo, Jalisco, Michoacán, Morelos and Querétaro).

Hosts. Muridae: Microtus mexicanus (Saussure, 1861), M. mexicanus phaeus, Microtus sp., Neotomodon alstoni Merriam, 1898, P. boylii levipes $=P$. levipes, $P$. difficilis $(\mathrm{J}$. A. Allen, 1891), P. hylocetes, $P$. maniculatus, $P$. melanosis (J. A. Allen and Champan, 1897), Peromyscus, and Reithrodontomys nest.

Comments. Very long setae on posterior margin of movable process (Fig. 10) as in S. machadoi and S. longicauda. Crochet similar to $S$. villai and S. tezontli. Characters of female terminal segments follow: dorsal antesensilial setae present, somewhat smaller than ventral one; single spermatheca with bulga slightly longer than wide, hilla about one and a half times as long as bulga, broadening towards apex, apex not much narrower than bulga, dorsal wall of hilla entering into bulga for about one third the length of the latter. The host preferences are mainly for 2 sympatric species of mice ( $P$. maniculatus and $P$. melanotis), parasitized by this flea in 6 of the 7 states where this flea has been found. The altitudinal range is more than $2600 \mathrm{~m}$. The type series included 4 male and 12 female paratypes collected from the same locality as the holotype, Mount Tancítaro, Michoacán on $M$. mexicanus phaeus, $P$. melanotis and $N$. alstoni.

Material examined. Mexico. Distrito Federal: La Venta, 22/XII/1951, 1 female ex P. truei, I. Bassols and A. Barrera (MZFC-S); 2 km NE Ajusco, 2/XI/1966, 1 male, 2 females ex Peromyscus, A. Ocaña (MZFC-S); Cuajimalpa, Cabeza del Toro, P. Nal. Desierto de los Leones, 3514 m (19¹7'27'N 99¹7'58'W), 8/II/2004, 1 male, 1 female ex P. maniculatus, H. Olguín (MZFC-S); Cuajimalpa $1 \mathrm{~km}$ del paraje Cruz Blanca sobre brecha corta fuego, Parque. Nal. Desierto de los Leones, 3020 m (19¹8'13.1'N 99¹9'34.1"'W), 28/II/2004, 1 male ex P. difficilis, H. Olguín (MZFC-S); Parres, 3100 m, 26/ VI/1965, 2 males, 4 females ex Peromyscus and N. alstoni, E. Martín (MZFC-S); idem 3000 m, 25/I/1965, 2 males, 6 females ex Peromyscus, E. Martín (MZFC-S); Contreras, $3300 \mathrm{~m}, 1 / \mathrm{XI} / 1966,1$ male, 2 females ex Peromyscus, T. Álvarez (MZFC-S); La Venta, 2850 m, 29/III/1952, 1 male ex P. hylocetes, I. Bassols and A. Barrera (MZFC-S). Estado de México: Lagunas de Zempoala, nr. Ojotongo, 2743 - 2788 m, 20, 24/III/1963, 2 males, 1 female ex Peromyscus and P. maniculatus, R. Traub, A. D. Stock, and J. H. Shaw (CMNH); Lagunas de Zempoala nr. Morelos, 2788 m, 18/III/1963, 1 male, 1 female ex Peromyscus, R. Traub (CMNH); Lagunas de Zempoala, La Cachucha, 2865 m, 24/III/1963, 1 male ex P. maniculatus, J. H. Shaw (CMNH). Hidalgo: El Chico, 13/VI/1952, 2 females ex $P$. maniculatus, R. MacGregor and A. Barrera (MZFC-S). Popocatépetl, $3100 \mathrm{~m}$, 9/X/1950, 1 female ex N. alstoni,
A. Barrera (MZFC-S); idem 28/X/1950, 2 females ex $P$. melanotis, A. Barrera and G. W. Wharton (MZFC-S); idem 11/VI/1952, 1 female ex $P$. hylocetes, A. Barrera and R. MacGregor (MZFC-S, USNM); Popocatépetl, 5.5 km S San Pedro Nexapa, 2800 m, 31/V/1964, 1 female ex Peromyscus, A. Barrera and T. Álvarez (MZFC-S); Popocatépetl, $5 \mathrm{~km} \mathrm{E}$, San Pedro Nexapa, $2700 \mathrm{~m}$, 30/V/1964, 6 males, 3 females ex P. maniculatus, A. Barrera and T. Álvarez (MZFC-S); Popocatépetl, San Pedro Nexapa, 19/IV/1964, 1 male, 2 females ex nest of Reithrodontomys, A. Barrera (MZFC-S); idem $2800 \mathrm{~m}$, 31/V/1964, 1 male, 2 females ex $P$. difficilis, A. Barrera (MZFC-S); idem 2700 m, 30/V/1964, 1 male, 2 females ex P. maniculatus, A. Barrera and T. Álvarez (MZFC-S). Jalisco: Nevado de Colima, 3322 m, 20/VII/1965, ex Microtus, ex M. mexicanus, 3 females (MZFC-S, USNM); idem 3352 m, 1 male, 2 females ex Microtus (CMNH); idem $2255 \mathrm{~m}, 8 / \mathrm{VII} / 1965,1$ female ex Peromyscus (USNM); Nevado de Colima, La Joya, 3352 m, 4, 18, 21-22, 28-29/VI/1965, 5 males, 5 females ex Microtus and P. melanotis, R. Traub (MWH, CMNH, USNM); 2, 5/ VII/1965, 1 male, 3 females ex Microtus (USNM); 3291 m, 22/VI/1965, 1 female ex Peromyscus (USNM); Nevado de Colima nr la Joya, 3352 m, 19, 21, 24, 27/VI/1965, 1 male, 4 females ex Peromyscus, $P$. melanotis, and $P$. hylocetes (USNM); Nevado de Colima, $6.4 \mathrm{~km} \mathrm{~W} \mathrm{La}$ Joya, 2895 m, 25/VI/1965, 2 females ex P. melanotis, R. Traub and E. M. Fisher (CMNH, USNM); idem $3352 \mathrm{~m}$, 25-26/VI/1965, 1 male, 2 females ex Microtus (USNM). Michoacán: Tancitaro, Mt Tancitaro, 3200-3505 m, 26/ VII/1941, 1 female ex M. mexicanus phaeus, R. Traub (BMNH), 2 males paratypes (USNM); idem 3352 m, 19, 22/VII/1941, 1 male ex P. melanotis, R. Traub (BMNH), 2 females paratypes (USNM). Morelos: km 42 carretera a Cuernavaca, 1 female ex unknown, A. Barrera (MZFC-S): 6.4-9.6 km N of Tres Marías, or Tres Cumbres, 1 male ex unknown, A. Barrera (CMNH). Querétaro: $1 \mathrm{~km} \mathrm{~S}$ de Pinal de Amoles, $2650 \mathrm{~m}, 6 / \mathrm{VIII} / 1982$, 1 female ex $P$. boylii levipes $=P$. levipes, JCM (MZFC-S).

\section{Strepsylla queretana Acosta, 2010}

Strepsylla queretana Acosta, 2010: 296.

Distribution.Mexico (Querétaro).

Host. Muridae: Peromyscus difficilis.

Comments. Base of lateral lobes wide, similar to S. fautini, toward apex narrow and rounded; dorsal lobes wide with a slightly deep cleft near the apex, similar to $S$. dalmati, and S. taluna. Crochet (Fig. 11) similar to S. ixtlanensis. Movable process with a few slender setae in dorsal margin (Fig. 12) as S. taluna. Neither the host preference nor the distribution can be accurately inferred with the existing data. Females unknown. 

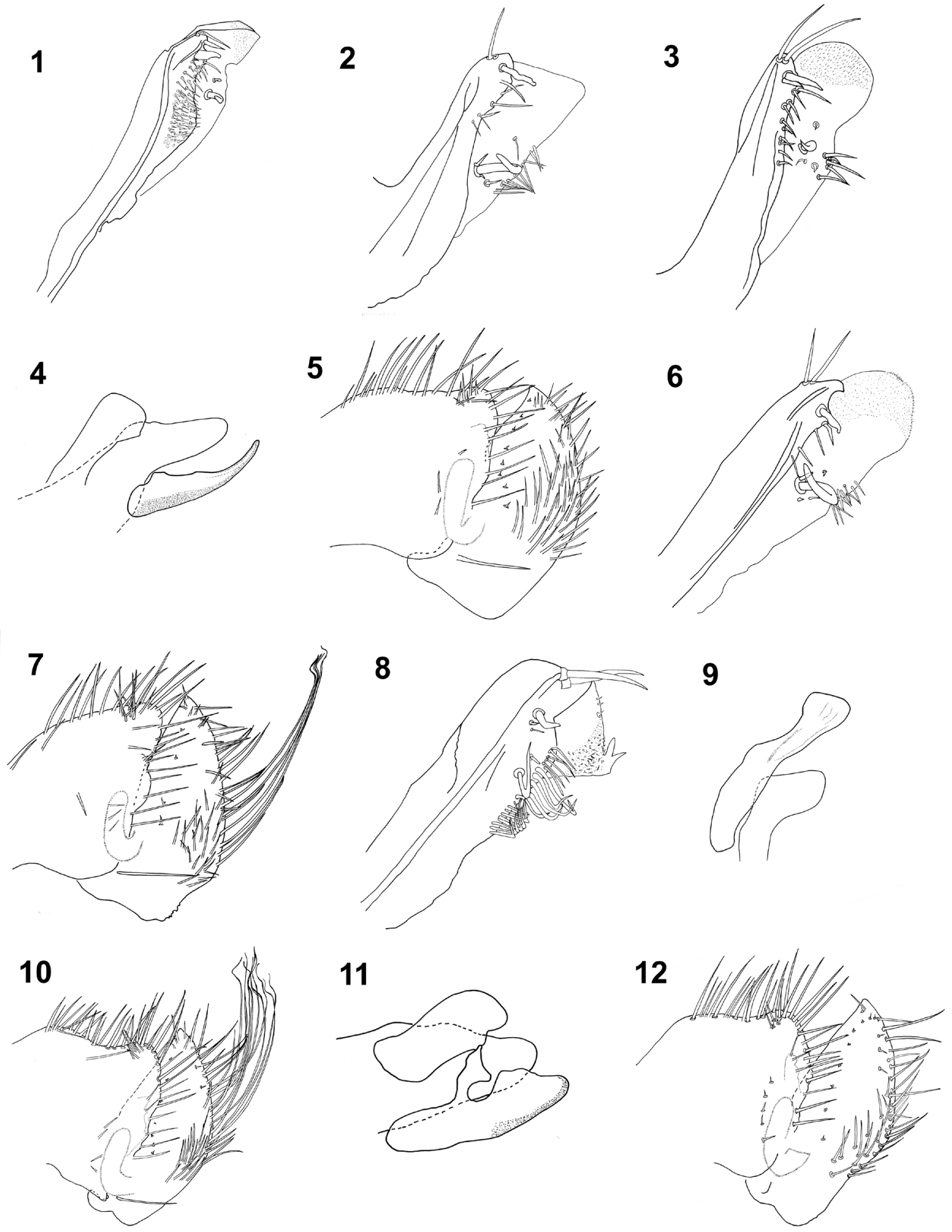

Figures 1-12. Male genitalia, disal arm of ninth sternite: (1), Strepsylla dalmati; (2), S. davisae; (3), S. fautini. Crochet, dorsal and lateral lobes: (4), S. fautini. Movable and fixed process (5). Distal arm of ninth sternite: (6), S. ixtlanensis. Movable and fixed process: (7), S. longicauda. Distal arm of ninth sternite: (8). Crochets, dorsal and lateral lobes: (9), S. machadoi. Movable and fixed process: (10), S. mina. Crochet, dorsal and lateral lobes: (11). Movable and fixed process: (12), S. queretana. 
Material examined. Mexico. Querétaro: Maguey Verde, 2290 m. Holotype male (03646 MZFC-S), 24/II/1983, E. Romo, ex P. difficilis.

Strepsylla schmidti Traub and Barrera, 1955

Strepsylla schmidti Traub and Barrera, 1955: 544.

Distribution. Mexico (Chiapas).

Host. Muridae: Peromyscus beatae Thomas, 1903.

Comments. Compared with S. dalmati, the crochet lacks a caudally directed upper lobe (Fig. 13) and the distal arm of sternite IX is ventrally straight and weakly sclerotized (Fig. 14). In the original publication, S. schmidti was separated from $S$. dalmati by the presence of 5 pairs of plantar setae, although the proximal pair is smaller than the others and displaced ventrally in the last segment of the metatarsus. Although typical, this character is not actually consistent in all the material examined. Neither the host preference nor distribution can be accurately inferred with existing data, so this species is in need of additional collecting.

Material examined. Mexico. Chiapas: Tzontehuitz, 2910 m, 10/VII/1965, 1 male ex P. beatae, D. L. Kilgore, Jr. (USNM); 17 km MW of Teopisca, 1981 m, 31/VII/1953, 1 male ex $P$. beatae, Furman and Price $(\mathrm{CMNH})$.

Strepsylla taluna Traub and Johnson, 1952

Strepsylla taluna Traub and Johnson, 1952: 547.

Distribution. Mexico (Distrito Federal, Estado de México, Morelos, and Tlaxcala).

Hosts. Muridae: Neotomodon alstoni, N. alstoni alstoni, Neotomodon sp., Peromyscus hylocetes, P. maniculatus labecula $=P$. maniculatus, and Peromyscus sp.; and Leporidae: Romerolagus diazi (Ferrari-Pérez in Diaz, 1898).

Comments. This species is similar to S. fautini and $S$. davisae because marginal setae on digitoid are relatively small (Fig. 15); distinctive in that lateral lobes of aedeagus are very broad and subtruncate apically and nearly equal in breadth. Male separable from S. mina, S. machadoi and $S$. longicauda by the absence of very long setae on posterior margin of movable process, distal arm of sternite IX (Fig. 16) more sickle-shaped and the poorly sclerotized ventral flange smaller than the other species except $S$. villai, ending distally far short of the apex of the arm; the large, twisted spiniform forming one spiral. Sternite IX with 2 antesensilial setae as $S$. villai and $S$. fautini. This flea was found on the endemic volcano mouse Neotomodon alstoni in 3 of the 4 states where it was collected and from another 4 species of rodents: however, the data support the need for additional collecting. This species has been previously collected in central Mexico. The record from Distrito Federal: km 43 on Cuernavaca highway, ex $R$. diazi is an accidental association, because Strepsylla does not parasitize lagomorphs.

Material examined. Mexico. Distrito Federal: El Zarco, 3000 m, 12/X/1951, 1 male ex P. hylocetes, A. Barrera (MZFC-S); La Venta, 2850 m, 21/IX/1951, 2 males ex $P$. maniculatus labecula $=P$. maniculatus, A. Barrera (MZFC-S); 22/XI/1951, 1 male ex $P$. maniculatus labecula $=P$. maniculatus, A. Barrera (CMNH); 29/ XII/1951, 1 female ex Peromyscus, A. Barrera (MZFC-S); Parres, $3100 \mathrm{~m}, 25 / \mathrm{I} / 1965,1$ male ex $N$. alstoni, E. Martín (MZFC-S); idem 2900 m, 10/VI/1965, 1 male ex Neotomodon, T. Álvarez (MZFC-S). Estado de México: 8 km W Río Frío, 3100 m, 17/I/1965, 5 males ex $N$. alstoni alstoni, T. Álvarez and A. Barrera (MZFC-S); Lagunas de Zempoala nr. Ojotongo, 2743 m, 23/III/1963, 2 males ex Neotomodon, R. Traub (MZFC-S, BMNH). Morelos: 1 km NE de Lagunas de Zempoala, 28/III/1954, 2 females ex $P$. maniculatus labecula $=P$. maniculatus, A. Barrera (MZFC-S); Lag. Zempoala, nr. Ojo de Agua, 2286 m, 25/III/1963, 1 male, 1 female ex Neotomodon, R. Traub (USNM). Tlaxcala: Altamira, La Malinche, caseta n. 5 (19²1.34'N 9806.62'W), 3040 m, 03/V/2003, 1 male ex Peromyscus, Jesús A. Fernández (MZFC-S).

Strepsylla tezontli Acosta, 2010

Strepsylla tezontli Acosta, 2010: 287.

Distribution. Mexico (Estado de Mexico).

Hosts. Muridae: Microtus mexicanus, Neotomodon alstoni, Peromyscus melanotis, and Peromyscus sp.

Comments. Fixed process of clasper with a marked concavity in dorsal margin (Fig. 17) as in $S$. mina. In $S$. tezontli the sinus is more prominent, sternite IX (Fig. 18) similar to $S$. villai, but the apex is more slender, slightly hooked and caudad. Crochet (Fig. 19) similar to S. villai, but the ventral arm is not as slender as $S$. villai and in S. mina is wider. Neither the host preference nor the distribution can be accurately inferred with the existing data (Acosta, 2010).

Material examined. Mexico. Popocatépetl: Tlamacas, 3850 m. Holotype male (0732 mZFC-S), 19/X/1963, Coll. A. Barrera; Paratypes: Iztaccíhuatl, Vertiente oriental, 3700 m, 23/I/1966, 1 female ex M. mexicanus, A. Barrera (MZFC-S); 3600 m, 1 male ex P. melanotis, A. Barrera and R. Muñiz (MZFC-S); Popocatépetl: Cerro Tlamacas, 3850 m, 19-20/X/1963, 2 males, 3 females ex P. melanotis, A. Barrera (MZFC-S); 1 km NE, Mirador del Poeta, 3900 m, 19/VII/1964, 2 males, 3 females ex Peromyscus, A. Barrera (MZFC-S); Popocatépetl, 3250 m, 23/XI/1963, 1 male ex $N$. alstoni, A. Barrera (MZFC-S); Popocatépetl: Cerro Tlamacas, 3900 m, 16/V/1964, 1 male, 5 females, ex N. alstoni, A. Barrera and T. Álvarez (MZFC-S); idem 5/VII/1964, 1 female ex N. alstoni, A. Barrera and 
T. Álvarez (MZFC-S); Otlaltepec, 2975 m, 1 male ex Peromyscus, A. Barrera (MZFC-S); Nexpayantla, 4000 m, 18/IX/1963, 2 females ex Peromyscus, A. Barrera and R. Muñiz (MZFC-S); 1 km NE, Mirador del Poeta, 3900 m, 19/VII/1964, 1 male ex Peromyscus (MZFC-S); Paso de Cortez, 3625 m, 9/I/1965, 1 male ex N. alstoni, T. Álvarez and A. Barrera (MZFC-S); Paraje Providencial, $3250 \mathrm{~m}$, 22/XI/1963, 1 male ex Peromyscus, A. Barrera (MZFC-S); Paraje Zumpango, $3100 \mathrm{~m}, 19 / \mathrm{VII} / 1964,1$ male ex $P$. melanotis, A. Barrera (MZFC-S): Iztaccíhuatl, Vertiente oriental, 3700 m, 23/I/1966, 1 male ex P. melanotis, A. Barrera (MZFC-S); idem 3600 m, 4 males, 1 female ex, M. mexicanus A. Barrera (MZFC-S): Río Frío, $3100 \mathrm{~m}$, 29/XI/1966, 1 male, 1 female ex Peromyscus, A. Barrera (MZFC-S).

Strepsylla vargasi Acosta, 2010

Strepsylla vargasi Acosta, 2010: 294.

Distribution. Mexico (Nuevo León and Zacatecas).

Hosts. Muridae: Peromyscus sp. and Sigmodon sp.

Comments. Separable from all known Strepsylla species except $S$. taluna and $S$. davisae in that the movable process is more slender (Fig. 20), with a scattered row of setae in the dorsal margin as $S$. taluna, fixed process similar to $S$. taluna. Neither the host preference nor the distribution can be accurately inferred with the existing data (Acosta, 2010).

Material examined. Mexico. Nuevo León: $7.4 \mathrm{~km} \mathrm{S,} 0.2$ km W San Josecito, 2670 m (Holotype) 3 males, 1 female ECMV2200, ECMV 2215 13/VI/1991, coll. M. Vargas (IBUNAM), ex Peromyscus; $5.2 \mathrm{~km} \mathrm{~N}, 0.2 \mathrm{~km}$ W San Josecito, 1600 m, 14/XI/1990, 1 female ex Peromyscus, M. Vargas, ECMV 2261 (IBUNAM). Zacatecas. $4.3 \mathrm{~km}$ N, 5.4 km E San Juan Capistrano, 1250 m, 21/XII/1987, 1 male ex Peromyscus, M. Vargas, ECMV 542 (IBUNAM). Nuevo León. 15/VI/1991, M. Vargas, ECMV 2614, 1 male ex Sigmodon, 3 females ex Peromyscus, M. Vargas. ECMV 2620, ECMV 2624, ECMV 2631 (IBUNAM).

Strepsylla villai Traub and Barrera, 1955

Strepsylla villai Traub and Barrera, 1955: 546.

Distribution. Mexico: Distrito Federal, Estado de México, Puebla, Querétaro, Tlaxcala, and Veracruz.

Hosts. Muridae: Neotomodon alstoni, N. alstoni alstoni, Neotomodon sp., Peromyscus difficilis amplus, $P$. maniculatus, P. melanotis, P. pectoralis (Osgood, 1904), $P$. truei (Shufeldt, 1885), Peromyscus sp., Reithrodontomys chrysopsis Merriam, 1900, and Reithrodontomys sp.

Comments. Distinguishable from S. mina by the small size of all the setae on the movable process (Fig. 21). Base of the sternite IX straight as S. mina, S. taluna, and S. fautini. Sternite VIII with a shallow subventral sinus in the posterior margin; distal arm of sternite IX (Fig. 22) similar as in S. taluna, but with more numerous setae, the feebly sclerotized flange larger. Apical crochet somewhat inverted C-shaped (Fig. 23), it is similar to S. tezontli. The main host is the volcano mouse Neotomodon alstoni, where it was found in 3 of the 6 states with records for this species, and secondly, mice of the genus Peromyscus with 5 species out of the 8 total species known as hosts. However, additional collecting is necessary, because 3 of the states have few records, and in some cases just 1 as in Veracruz and Puebla.

Material examined. Mexico. Distrito Federal: Pedregal de San Angel, 9/V/1964, 1 female ex P. truei, C. E. Aviña (MZFC-S); Cuajimalpa, Cabeza del Toro, Parque Nal. Desierto de los Leones, 3514 m (19²17'27'N 99 $\left.{ }^{\circ} 17^{\prime} 58^{\prime \prime} \mathrm{W}\right), 8 / \mathrm{II} / 2004,1$ female ex Reithrodontomys, $\mathrm{H}$. Olguín (MZFC-S); 2 km SW Parres, 2900 m, 10/VI/1965, 2 females ex Neotomodon, T. Álvarez (MZFC-S); 23/ VII/1965, 1 female ex Neotomodon, E. Martín (MZFC-S): Popocatépetl, Diego de Ordaz, 3250 m, 24/XI/1963, 2 females ex P. maniculatus, A. Barrera and T. Álvarez (MZFC-S); Popocatépetl, Mirador del Poeta, 3900 m, 5/VII/1964, 2 females ex P. melanotis, A. Barrera and T. Álvarez (MZFC-S); Popocatépetl, Paraje Providencial, $3250 \mathrm{~m}$ 23, 24/XI/1963, 2 females ex P. melanotis, P. maniculatus, A. Barrera and T. Álvarez (MZFC-S); Popocatépetl, Pie del Ventorrillo, 4200 m, 19/VII/1964, 1 female ex Peromyscus, A. Barrera (MZFC-S); Popocatépetl, Tlamacas, 3850 m, 30/X/1963, 2 females ex P. melanotis, unspecified host, A. Barrera and R. Muñiz (MZFC-S); Popocatépetl, Zumpango, 3100 m, 19/VIII/1964, 1 female ex unspecified host, A. Barrera (MZFC-S). Estado de México: Río Frío, 3100 m, 28/XII/1966, 2 males ex $N$. alstoni alstoni, A. Barrera (MZFC-S); 8 km W Río Frío, $3100 \mathrm{~m}, 17 / \mathrm{I} / 1965,5$ females ex N. alstoni, A. Barrera and T. Álvarez (MZFC-S). Puebla: 1 km SW San Pedro Atlixco, $2200 \mathrm{~m}, 22 / \mathrm{II} / 1964,1$ male, 1 female ex unspecified host, A. Barrera and T. Álvarez (MZFC-S); Atzitzintla, Sta. Cruz Cuyachapa, Ejido de Maguey Cenizo, $2570 \mathrm{~m}$ (18 $53^{\prime} 16^{\prime \prime N} 97^{\circ} 20^{\prime} 23$ 'W), 1 female ex Peromyscus, Jesús A. Fernández (MZFC). Querétaro: Tolimán, El Derramadero, 9/V/1996, 1 male ex $P$. pectoralis, $\mathrm{R}$. Acosta (MZFC-S). Tlaxcala: Holotype: male, $10 \mathrm{~km} \mathrm{E}$ of Calpulalpan, 23/VIII/1952, ex $P$. difficilis amplus, B. Villa (USNM); $10 \mathrm{~km}$ NE Calpulalpan, $3100 \mathrm{~m}, 26 /$ VI/1965, 1 male, 1 female ex Neotomodon, E. Arrington (MZFC-S); Tlaxco, 2/IV/1959, 1 male ex Peromyscus, T. Álvarez (MZFC-S); Huamantla, La Malinche, caseta n. 4, 15/VI/2003, 1 female ex $R$. chrysopsis, Jesús A. Fernández (MZFC-S); 3/V/2003, 1 male ex $N$. alstoni, Jesús A. Fernández (MZFC-S); Sanctorum, por el camino Rural a Benito Juárez, La Joya, 2755 m (19³1'53”N 
13
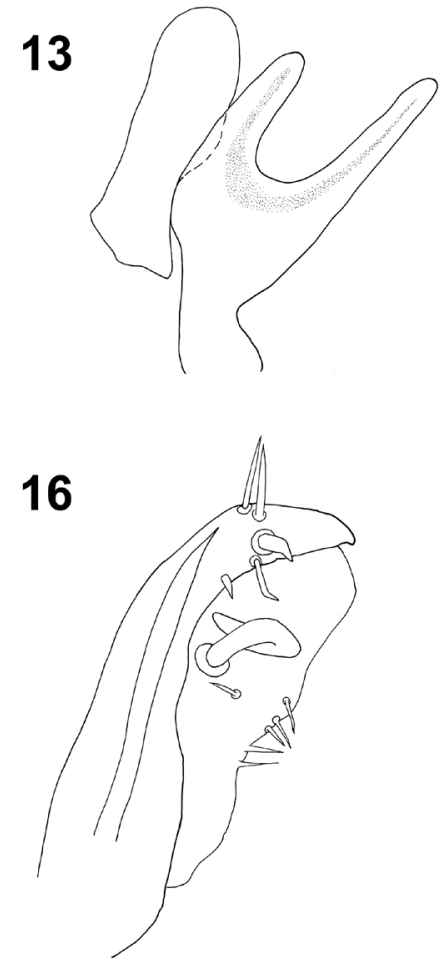

19

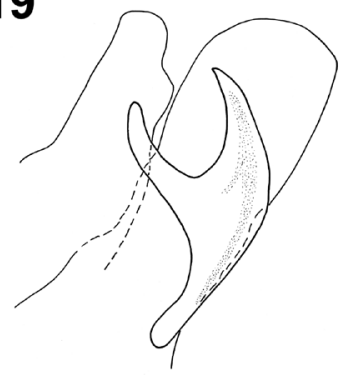

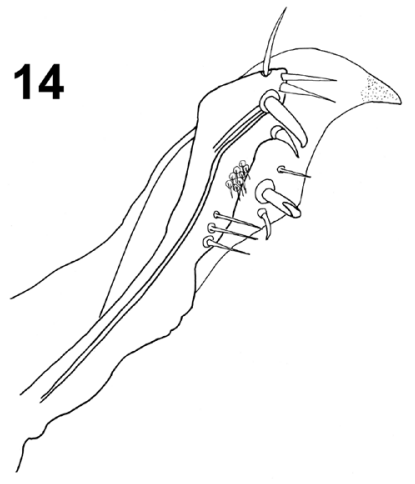

17
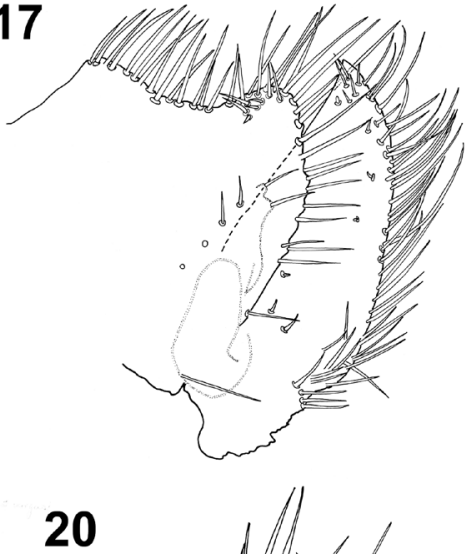

20

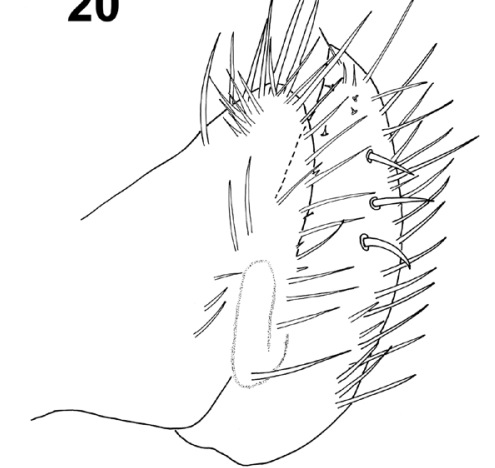

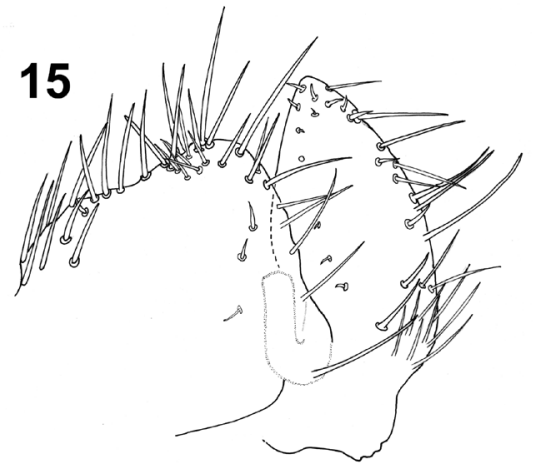

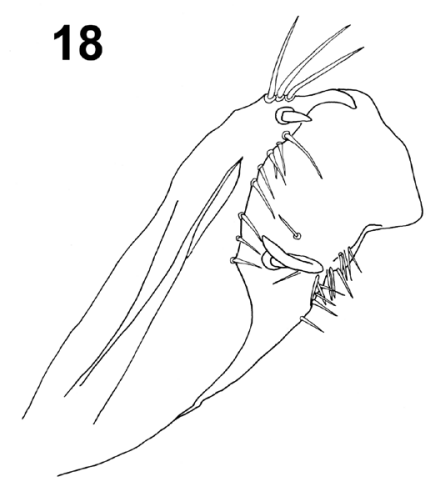

21

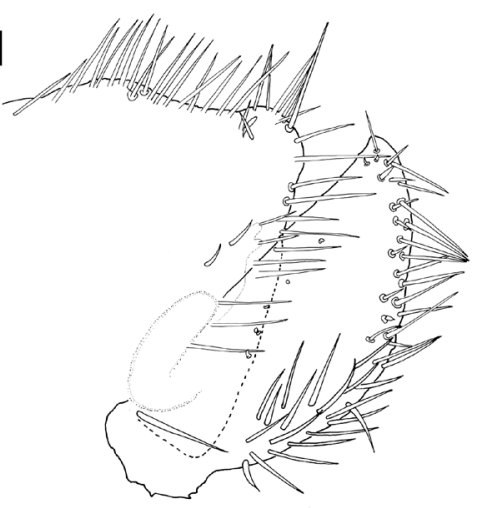

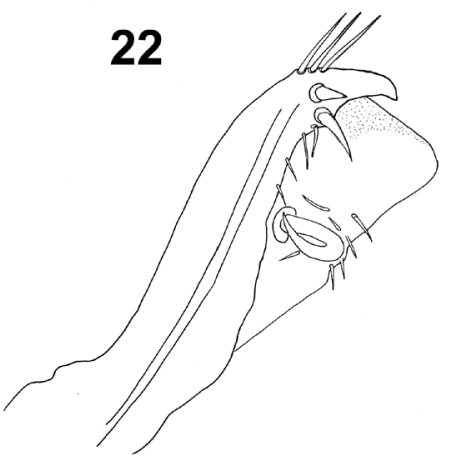

23

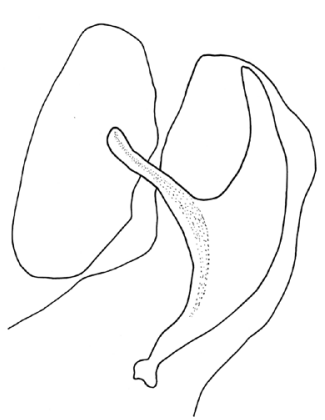

Figures 13-23. Male genitalia. Crochet, dorsal and lateral lobes: (13). Distal arm of ninth sternite: (14), Strepsylla schmidti. Movable and fixed process: (15). Distal arm of ninth sternite: (16) S. taluna. Movable and fixed process: (17). Distal arm of ninth sternite: (18). Crochets, dorsal and lateral lobes: (19), S. tezontli. Movable and fixed process: (20), S. vargasi; (21), S. villai. Distal arm of ninth sternite: (22). Crochet, dorsal and lateral lobes: (23) S. villai. 
98²6’03”W), 20/II/2004, 1 female ex Peromyscus, Jesús A. Fernández and R. Acosta (MZFC-S). Veracruz: Cofre de Perote, 3000 m, 2/V/1968, 2 females ex Reithrodontomys, E. Martín (MZFC-S).

\section{Acknowledgments}

To Juan J. Morrone, for comments on the manuscript. To the curators who loaned the specimens and type material studied herein: Nancy Adams (deceased) and David G. Furth, National Museum of Natural History, Smithsonian Institution, Washington, D.C.; James H. Boone, Field Museum of Natural History, Chicago; Prof. Ralph P. Eckerlin, Northern Virginia Community College, Annandale, Virginia; John E. Rawlins, Carnegie Museum of Natural History, Pittsburgh; Michael W. Hastriter, Brigham Young University, Provo, Utah; Theresa Howard, The Natural History Museum, London; Juan J. Morrone, Museo de Zoología, Facultad de Ciencias, UNAM, Mexico, D.F.; and Margarita Vargas.

Jesús A. Fernández for hand carrying material from the USA. Funding for this study was provided by CONACyT (grant 200243) and Programa de Apoyo a Proyectos de Investigación e Innovación Tecnológica (PAPIIT-UNAM) IN205408; Dirección General de Estudios de Posgrado (DGEP-UNAM) and the Museo de Zoología for provision of working space, equipment, supplies, and general support required for this work.

\section{Literature cited}

Acosta, R. 2010. Five new Mexican species of the flea genus Strepsylla Traub, 1950 (Siphonaptera: Ctenophthalmidae: Neopsyllinae: Phalacropsyllini) with a phylogenetic analysis. Journal of Parasitology 96:285-298.

Adams, N. E. and R. Lewis. 1995. An annotated catalog of primary types of Siphonaptera in the National Museum of Natural History, Smithsonian Institution. Smithsonian Contributions to Zoology 560:1-86.

Barrera, A. and R. Traub. 1963. Notas sobre sifonápteros X.- Descripción de Strepsylla machadoi nov. sp. (Siph. Hystrichops., Neops.). Ciencia (Mex) 22:191-196.

Hopkins, G. H. and M. Rothschild. 1962. An illustrated catalogue of the Rothschild collection of fleas (Siphonaptera) in the British Museum (Natural History) III. Hystrichopsyllidae (Acedestiinae, Anomiopsyllinae, Hystrichopsyllinae, Neopsyllinae, Rhadinopsyllinae and Stenoponiinae). British Museum (N.H.). 560 p.

Medvedev, S. G. 1996. Geographical distribution of families of fleas (Siphonaptera). Entomological Review 76:978-992.

Medvedev, S. G. 2000. Fauna and Host-Parasite associations of fleas (Siphonaptera) in different zoogeographical regions of the World: II. Entomological Review 80:640-655.

Traub, R. 1950. Siphonaptera of Central America and Mexico: A morphological study of the aedeagus with descriptions of new genera and species. Fieldiana, Zoology 1:1-127.

Traub, R. and A. Barrera. 1955. Three new fleas of the genus Strepsylla Traub (Siphonaptera: Hystrichopsyllidae). Fieldiana, Zoology 37:541-550.

Traub, R. and P. T. Johnson. 1952. Four new species of fleas from Mexico (Siphonaptera). American Museum Novitates 1598:1-28. 